\title{
Factors Influencing Initial Trust in Cellphone Recycling Website: The Moderating Role of Consumers' Environmental Awareness
}

\author{
Mingying Dong ${ }^{1, \text { a }}$, Chunfa $\mathrm{Li}^{1}$ and Xiaohao Zhou ${ }^{1, \mathrm{~b}}$ \\ ${ }^{1}$ School of Management, Tianjin University of Technology, Tianjin300384, China

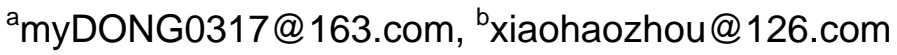

\begin{abstract}
Keywords: Cellphone recycling website, Initial trust, Influencing factors, Moderating effect, Structural equation modeling
\end{abstract}

\begin{abstract}
Cellphone recycling website with advantages such as convenience, efficiency, professionalism and environmental protection, and many other advantages, has become into a new channel for recycling of waste cellphones. And the key for its popularity and successful operation is to obtain the initial trust of consumers. For the influencing factors of initial trust of websites, scholars have researched a lot from the aspects of site factors, consumer and environmental factors. On the basis of previous studies, this paper combines with the characteristics of cellphone recycling sites, considers the effects the environmental responsibility performance of recycling sites and consumer awareness of environmental protection have on initial trust.
\end{abstract}

\section{Introduction}

Initial trust is the important research content in the field of electronic commerce, many scholars have carried out empirical studies on the influencing factors of initial trust in websites, and the influencing factors include the site factors, consumer factors and environmental factors.

Kim[1] ,Palvia[2], Koufaris[3] researched the influencing factors on initial trust of website from the point of website design, results showed that website reputation, website usefulness and website ease of use were the three main factors that had important influence in the establishment of initial trust; Cheung [4] researched the influencing factors on initial trust of website from the point of consumers, results showed that consumers' trust propensity had significant impact on initial trust; Cummings[5] studied the influencing factors on initial trust of website from the point of outside environment ,and fond that the structural security of the website was an important factor in the formation of initial trust.

According to the previous research and combined with the characteristics of cellphone recycling website, this paper discusses and analyzes the effect the two factors that the responsibility of environmental protection of the website and consumers' environmental awareness have on initial trust in cellphone recycling website.

\section{Theoretical Research and Hypothesis}

Environmental Protection of the Website. In the field of trust research, Scholars have recognized the importance of corporate social responsibility in the generation of consumer trust. The researches of Castaldo[6] and Hongli Zhang [7] showed that the corporate social responsibility performance of retailers significantly affects the trust of consumers to the enterprise; Other researchers found that corporate social responsibility performance influence the consumer's trust to the enterprise brand, and thereby affect consumer purchase behavior. Sheng $\mathrm{Hu}$ [8] verified that consumers' social responsibility support moderated the relationship between corporate social responsibility and trust, when the enterprise has a positive social responsibility, consumers will be more likely to trust the enterprise. Thus we have the hypothesis as follows. 
H1: Environmental responsibility of recycling websites has a positive impact on the formation of initial trust.

Consumer Awareness of Environmental Protection. Environmental protection is one of the important contents of corporate social responsibility. With the importance of corporate social responsibility and the improvement of consumer awareness of social responsibility, researches on corporate social responsibility showed that the goal of the enterprise is not only to pursue the economic benefits, but also pay more attention to the commitment to social responsibility. Corporate social responsibility can affect consumers' behavior intention and specific behavior, and consumer's sense of social responsibility will affect the performance of corporate social responsibility. Sen et al [9] studied that consumers' support of corporate social responsibility has an mediating role between corporate social responsibility and consumer purchasing behavior, that means consumers are more willing to buy the product of the enterprise when it is perceived by the consumers that the enterprise are positively to take the social responsibility. Thus we have the hypothesis as follows.

$\mathrm{H} 2$ : The stronger consumer awareness of environmental protection, the greater the impact of environmental responsibility on the initial trust

According to the above theoretical analysis and research hypothesis, this paper puts forward the research model as shown in Figure 1



Fig. 1 Research Model of Initial Trust Building in Recycling Website

\section{Empirical Research}

In the empirical study, 400 questionnaires were distributed, 318 were recovered, 20 questionnaires were excluded, 298 were valid questionnaires, and the effective recovery rate was $74.5 \%$. The basic information of the survey object is shown in Table 1.

Table 1 Descriptive Statistics of the Respondents' Characteristics

\begin{tabular}{llllllll}
\hline \multicolumn{2}{c}{ sex } & \multicolumn{2}{c}{ age } & \multicolumn{2}{c}{ education } & \multicolumn{2}{c}{ monthly income } \\
\hline sex & ratio & age & ratio & education & ratio & monthly income & ratio \\
\hline male & $44.3 \%$ & $\leq 20$ & $26.17 \%$ & middle school & $3.69 \%$ & $\geq 10000$ & $4.03 \%$ \\
female $55.7 \%$ & $20-30$ & $50.67 \%$ & A-Level & $17.11 \%$ & $5000-10000$ & $17.45 \%$ \\
\multicolumn{2}{l}{ Old cellphone } & $30-40$ & $17.11 \%$ & college & $16.78 \%$ & $3000-5000$ & $17.79 \%$ \\
yes & $84.23 \%$ & $\geq 40$ & $6.05 \%$ & Undergraduate & $33.89 \%$ & $2000-3000$ & $13.42 \%$ \\
no & $15.77 \%$ & & & graduate & $28.53 \%$ & $\leq 2000$ & $47.31 \%$ \\
\hline
\end{tabular}

Basic Hypothesis Test. Using Amos to carry on the hypothesis test, the hypothesis test path analysis and the standard estimate result as shown in Figure 2. 


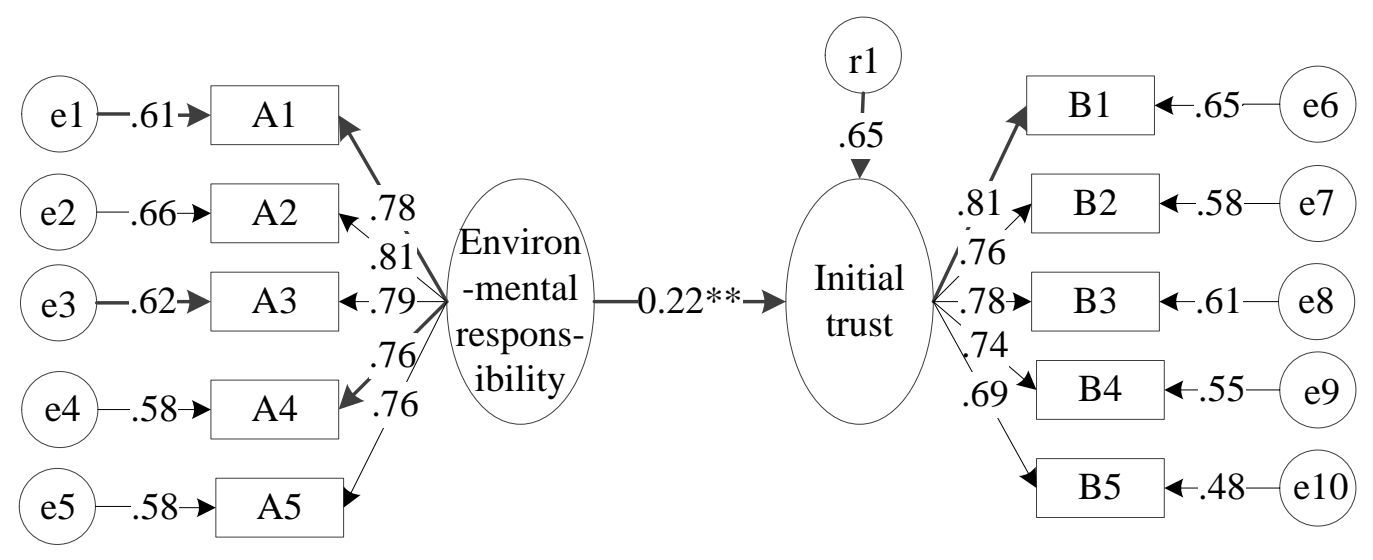

Fig. 2 Amos path analysis and Standardized results

As shown in Figure 2, the role of the environmental responsibility of the site in the formation of initial trust through the significant test, the result supports the Hypothesis 1.

Mediating Effect Test. Spss19.0 software was used to carry out layer by layer regression analysis, the results as shown in Table 2.

Table 2 Analysis of Moderating Effect

\begin{tabular}{|c|c|c|c|c|c|}
\hline \multirow{2}{*}{ Variate } & \multirow{2}{*}{ Hypothesis } & \multicolumn{3}{|c|}{ Initial trust } & \multirow[b]{2}{*}{ Model 4} \\
\hline & & Model1 & Model 2 & Model 3 & \\
\hline control variable & & & & & \\
\hline sex & & -0.019 & 0.014 & 0.013 & 0.015 \\
\hline age & & -0.008 & 0.029 & 0.030 & -0.009 \\
\hline education & & -0.015 & -0.016 & -0.016 & -0.012 \\
\hline monthly income & & $0.068^{*}$ & $0.0471^{*}$ & $0.049^{*}$ & $0.047^{*}$ \\
\hline old cellphones & & 0.165 & 0.085 & 0.085 & 0.105 \\
\hline $\begin{array}{l}\text { Independent Variable } \\
\text { Environmental responsibility }\end{array}$ & H6 & & $0.566^{* * *}$ & $0.566^{* * *}$ & $0.569^{* * *}$ \\
\hline $\begin{array}{l}\text { Moderator Variable } \\
\text { Environmental awareness } \\
\end{array}$ & & & & 0.016 & 0.014 \\
\hline $\begin{array}{l}\text { interaction effect } \\
\text { awareness * responsibility }\end{array}$ & H7 & & & & $0.158^{* * *}$ \\
\hline $\mathrm{R}^{2}$ & & 0.036 & 0.405 & 0.405 & 0.420 \\
\hline$\Delta \mathrm{R}^{2}$ & & 0.036 & 0.369 & 0.000 & 0.015 \\
\hline F-value & & 1.804 & $28.177^{* * *}$ & $24.618^{* * *}$ & $23.220^{* * *}$ \\
\hline
\end{tabular}

Note: *express $\mathrm{P}<0.05, * *$ express $\mathrm{P}<0.01, * * *$ express $\mathrm{P}<0.001$

Result Analysis. Through the empirical analysis, we can know that hypothesis 1 and hypothesis 2 are established. Environmental responsibility of recycling websites has a positive impact on the formation of initial trust, and consumer awareness of environmental protection has a mediating role between Environmental responsibility and initial trust.

\section{Summary}

Environmental responsibility of recycling websites has a significant impact on t initial trust, and consumer awareness of environmental protection has a mediating effect between them. It indicates that the recycling websites should take the responsibility of environmental protection as one of the goals of its development, and should not only pursue economic benefits. At the same time, strengthen 
environmental advocacy, will be helpful to gain the trust of consumers. When consumers have a high awareness of environmental protection, the environmental behavior of recycling websites will have a more significant impact on the consumer's initial trust.

\section{References}

[1] H.W. Kim, Y.J. Xu, A comparison of online trust building factors between potential customers and repeat customers, Journal of the Association for Information Systems, 10(2004)392-420.

[2] P. Palvia, The role of trust in e-commerce relational exchange: A unified model, Information and Management, 46 (2009)213-220.

[3] M. Koufaris, M. Hampton-Sosa, The development of initial trust in an online company by new customers, Information and Management,41(2004) 377-397.

[4] C. Cheung, M. Lee, Trust in internet shopping: a proposed model and measurement instrument, Proceedings of the 2000 Americas Conference on Information Systems, (2000)681-9.

[5] D.H. McKnight, L.L. Cummings and N.L. Chervany, Initial trust formation in new organizational

Relationships, Academy of Management Review, 23 (1998) 473-490.

[6] S. Castaldo, F. Perrini and N. Misani, The missing link between Corporate Social Responsibility and consumer Trust: The Case of Fair Trade Products, Journal of Business Ethics, (2009)1-15.

[7] H.L. Zhang, The impact of corporate social responsibility on consumer trust, Journal of Changchun University of Science and Technology (Social Science Edition),23(2010)27-29. (In Chinese)

[8] S. Hu, A study of impact of the consumer perspective CSR on consumers' trust, Zhejiang University,(2010). (In Chinese)

[9] S. Sen, C.B. Bhattacharya, Does doing good always lead to doing better? Consumer reactions to Corporate Social Responsibility, Journal of Marketing Research, 38(2001) 225-243. 